\title{
New Approaches on Cancer Immunotherapy
}

\author{
Jong-Ho Cha, ${ }^{1,2}$ Li-Chuan Chan, ${ }^{1,3}$ Min Sup Song, ${ }^{1}$ and Mien-Chie Hung ${ }^{13,4,5}$ \\ ${ }^{1}$ Department of Molecular and Cellular Oncology, University of Texas MD Anderson Cancer Center, Houston, \\ Texas 77030, USA \\ ${ }^{2}$ Department of Biomedical Sciences, College of Medicine, Inha University, Incheon 22212, South Korea \\ ${ }^{3}$ Graduate School of Biomedical Sciences, University of Texas Health Science Center, Houston, Texas \\ 77030, USA \\ ${ }^{4}$ Graduate Institute of Biomedical Sciences and Center for Molecular Medicine, China Medical University, \\ Taichung 404, Taiwan \\ ${ }^{5}$ Department of Biotechnology, Asia University, Taichung 413, Taiwan \\ Correspondence: mhung@mail.cmu.edu.tw or mhung77030@gmail.com
}

\begin{abstract}
Metastasis, which occurs when cancer cells disseminate from the primary tumor site to other parts of the body, is the primary cause of mortality in patients, and the recurrence of multiple metastatic tumors is an obstacle to eliminating cancer. Recent clinical studies demonstrated that patients who respond to immunotherapy have longer survival rates with lower metastatic relapse, suggesting that immunotherapy may be one of the solutions to overcome cancer metastasis. Indeed, various host immune cells not only shape the tumor microenvironment but also participate in multiple stages of metastasis. Therefore, to improve clinical outcome, it is critical to understand the immunological events associated with tumor development and progression. In this article, we summarize those events that are involved in tumor progression and discuss immunotherapies that can potentially target cancer metastasis.
\end{abstract}

$\mathrm{O}$ ver the last two decades, various therapeutic approaches have been developed based on remarkable findings in the field of immuno-oncology. For example, cancer vaccines and chemokine therapy have been shown to increase the sensitivity and activity of immune cells against tumor cells (Papaioannou et al. 2016). In addition, antibodies targeting cancer immune checkpoints, including cytotoxic T-lymphocyte-associated protein 4 (CTLA-4), programmed death-ligand (PD-L1), programmed death-1 (PD-1), lymphocyte-activation gene 3 (LAG-3), galectin-9 (Gal-9), and
T-cell immunoglobulin and mucin-domaincontaining-3 (TIM3), have demonstrated promising results by restoring the patients' depleted immune system (Pardoll 2012). Moreover, adoptive cell transfer (ACT), such as dendritic cell (DC) vaccine, chimeric antigen receptor $T$ (CAR-T) cell therapy, and CARnatural killer (NK) cell therapy (Liu et al. 2017; Harrer et al. 2018), has emerged as another effective cancer treatment modality. Currently, two CAR-T cell therapies are approved by the U.S. Food and Drug Administration (FDA) for lymphoma: axicabtagene ciloleucel

Editors: Jeffrey W. Pollard and Yibin Kang

Additional Perspectives on Metastasis: Mechanism to Therapy available at www.perspectivesinmedicine.org

Copyright (C) 2020 Cold Spring Harbor Laboratory Press; all rights reserved; doi: 10.1101/cshperspect.a036863

Cite this article as Cold Spring Harb Perspect Med 2020;10:a036863 
J.-H. Cha et al.

(Yescarta) and tisagenlecleucel (Kymriah) (Dwivedi et al. 2019).

Although the clinical trials for the abovementioned immunotherapies have revealed significant antitumor effects against certain types of cancer, such as metastatic melanoma, B lymphoma, and non-small-cell lung cancer, they are limited in most solid tumors (Armand et al. 2013; Antonia et al. 2016; Seidel et al. 2018). Interestingly, patients with high response to immunotherapy have longer survival rates with reduced recurrence (Grossmann and Margolin 2015; Gauci et al. 2019), suggesting that immunotherapy may also target undetectable disseminated cancer cells in addition to primary tumor cells and reduce metastasis. Below, we discuss the immune response related to cancer malignancy during tumor development and progression, summarize the findings of current major immunotherapies, and offer some additional insights into the advances in immunotherapy with respect to cancer metastasis.

\section{Immune Response in Tumor Development}

The development of tumor occurs in multiple stages: initiation, promotion, and progression (Fig. 1A; Armitage 1985). During the initiation stage, DNA damage induced by carcinogenic factors, for example, genetic mutations, chemical carcinogens, radiation, and viral infection, up-regulates oncogenes and inhibits tumor suppressor genes, leading to the transformation of the initiated cells (Fig. 1A; Basu 2018). The growth factors and survival signals then activate oncogenes to facilitate the formation of neoplasm by inducing amplified cell proliferation of the initiated cells (Fig. 1A). In addition, such uncontrolled growth greatly increases the likelihood of mutations (Hanahan and Weinberg 2011). Meanwhile, cancer cells struggle fiercely to survive against the immune response. This dynamic process, also known as immunoediting, consists of three phases, elimination, equilibrium, and escape (Fig. 1B; Dunn et al. 2002; Kim et al. 2007). Cancer cells that overcome immune defense can develop into tumors, and as they grow in the progression stage, interactions with various types of host cells occur to establish a protumor microenvironment that fosters invasion and metastasis (Fig. 1A; Wang et al. 2017).

\section{The Elimination Phase}

During the elimination phase, most cancer cells are removed via immunosurveillance by both innate and adaptive immunity (Fig. 1B; Swann and Smyth 2007). The primary effectors in the innate immune response are NK cells and immunostimulatory macrophages (Bellora et al. 2010). NK cells recognize cancer cells with low levels of nonclassical major histocompatibility complex (MHC) I and secrete cytotoxic perforin and granzymes to lyse them (Marcus et al. 2014). Meanwhile, proinflammatory cytokines in the tumor, such as TNF- $\alpha$ and IFN- $\gamma$, secreted by NK and Type 1 Helper T (TH1) cells instruct monocytes to differentiate into immunostimulatory macrophages to phagocytize cancer cells (Mosser and Edwards 2008; Braumüller et al. 2013). Activated macrophages also support adaptive immunity by secreting interleukin-12 (IL-12), which can stimulate the proliferation and activity of $\mathrm{T}$ cells, for example, $\mathrm{TH} 1$ and cytotoxic T lymphocytes (CTLs) (Mosser and Edwards 2008). Moreover, phagocytic macrophages and DCs present tumor antigen to TH1 cells and CTLs in the lymph node drainage. The educated $\mathrm{T}$ cells with antigen-specific long-term memory then home to the tumor site to kill the remaining cancer cells (Gajewski et al. 2013).

\section{The Equilibrium Phase}

A small number of cancer cells that survive the elimination phase undergo repeated proliferation and elimination, allowing them to enter the equilibrium phase and survive without tumor formation (Dunn et al. 2002). In clinical experience, the equilibrium phase may be the longest of the three phases of the immune response in tumor development and could last for many years (Kim et al. 2007), during which cancer cells may accumulate various resistant mutations against immunosurveillance (Fig. 1B). 

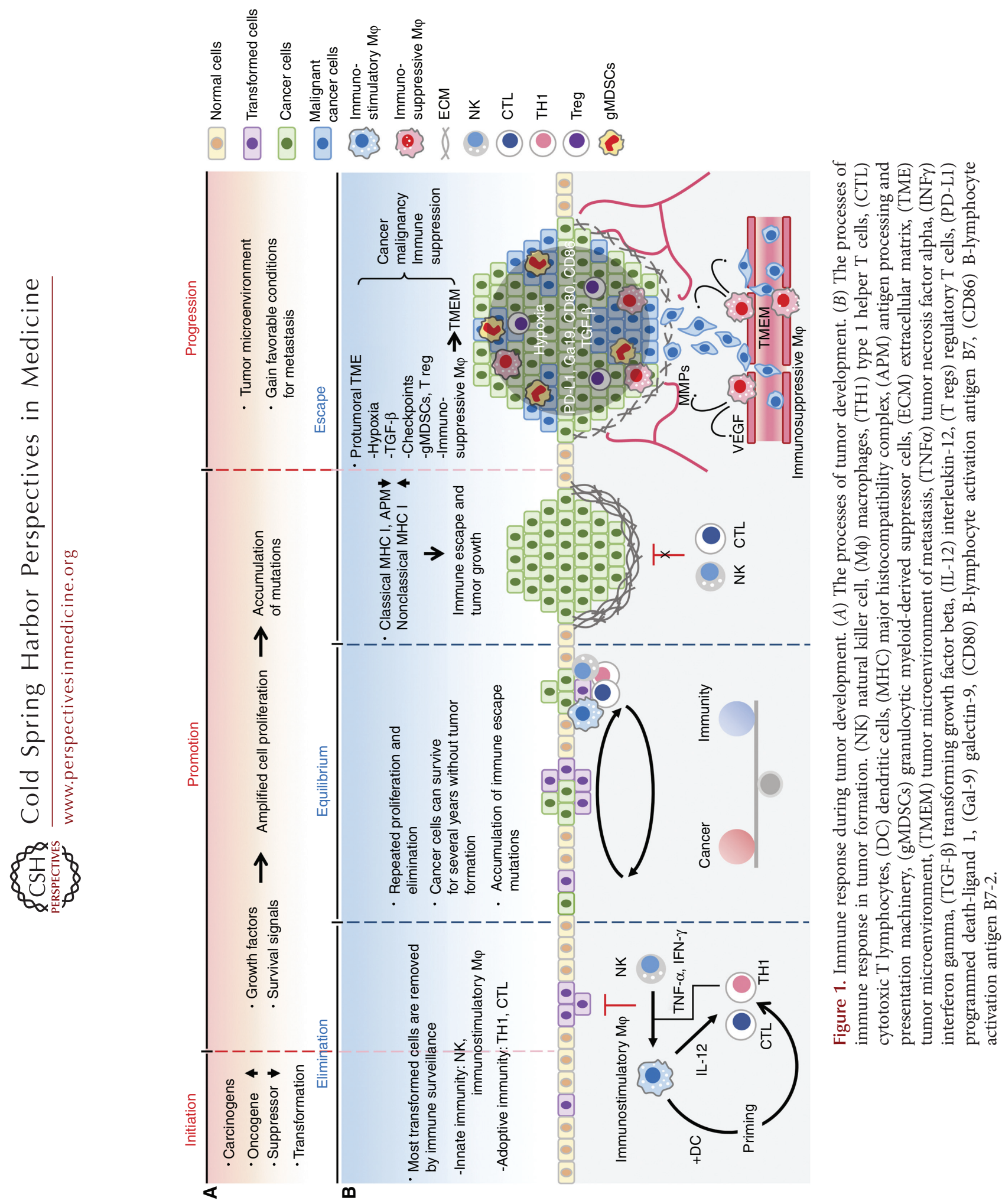
J.-H. Cha et al.

\section{The Escape Phase}

In the escape phase, the equilibrium between the cancer cell growth and its elimination by immunity becomes favorable toward cancer cells, and various genetic and epigenetic alterations that may have accumulated during the equilibrium phase provide cancer cells the stealth ability to evade immune recognition. It has been reported that select cancer cells harbor abnormalities in $\mathrm{MHC}$ levels and the related-antigen processing and presentation machinery (APM) that plays a role in displaying cancer antigen peptides to CTLs and NK cells (Leone et al. 2013). Most tumor cells exhibit down-regulation or loss of classical MHC class I molecules (HLA-A, HLA-B-, HLA-C) and APM, hindering their recognition by CTLs. Moreover, tumor cells also increase the levels of nonclassical MHC class I molecules (Kochan et al. 2013; Halenius et al. 2015), thereby blocking attacks by NK cells. Eventually, those that escape from the immune system form tumors (Fig. 1B, left).

\section{The Tumor Microenvironment and Cancer Malignancy}

As tumors grow, the tumor microenvironment (TME) is established through complex interactions between cancer cells and activated host stroma (Fig. 1B, right). In a protumoral microenvironment, the presence of inhibitory immune checkpoints, hypoxia, inflammatory cytokines, immunosuppressive tumor-associated macrophages (TAMs), regulatory T cells (T regs), and granulocytic myeloid-derived suppressor cells (gMDSCs) (Balkwill et al. 2012; Barcellos-Hoff et al. 2013), facilitates metastasis by providing favorable conditions before and after cancer invasion, and suppressing antitumor immunity (Quail and Joyce 2013; Mascaux et al. 2019).

Immune checkpoint molecules are abundantly expressed in the TME and regulated by adaptive signaling and intrinsic oncogenic pathways (Topalian et al. 2015). Hypoxia and cytokine signaling, such as TNF- $\alpha$, and IFN- $\gamma$, are the dominant adaptive signaling pathways that upregulate immune checkpoint molecules (both mRNA and proteins). The intrinsic oncogenic pathways, including epigenetic alternations, epidermal growth factor receptor (EGFR), MYC, KRAS, and AKT, increase the RNA levels of immune checkpoint molecules (Parsa et al. 2007; Akbay et al. 2013; Casey et al. 2016; Coelho et al. 2017).

Previously, $\mathrm{Xu}$ et al. reported that intratumoral hypoxia promotes epithelial-mesenchymal transition (EMT) of cancer cells by up-regulating EMT-inducible factors, for example, transforming growth factor-beta (TGF- $\beta$ ) (Xu et al. 2009), which possess strong immunosuppressive effects (Yang et al. 2010). Furthermore, hypoxia increases the release of chemoattractants, such as colony stimulating factor 1 (CSF1), endothelial-monocyte-activating polypeptide II (EMAP II), endothelin 2 (ET 2 ), and vascular endothelial growth factor (VEGF) (Murdoch et al. 2004), resulting in the recruitment of TAMs that are critical to cancer cell dissemination. Various chemoattractants released from the TME recruit $\mathrm{T}$ regs to help suppress other types of immune cells by secreting immunosuppressive cytokines, for example, TGF- $\beta$, IL-10, and IL-35 (Chaudhary and Elkord 2016). T regs can also inhibit the activity of effector $\mathrm{T}$ cells through coinhibitory checkpoint signaling and IL-2 consumption. In addition, $\mathrm{T}$ regs can indirectly neutralize adaptive immunity by reducing the antigen-presenting activity of DCs (Schmidt et al. 2012). In the tumor microenvironment of metastasis (TMEM) consisting of macrophages, vessel endothelium, and cancer cells, angiopoietin receptor-positive $\left(\mathrm{Tie} 2^{+}\right)$TAMs have been shown to enhance vessel leakage and remodel the extracellular matrix (ECM) by secreting high levels of VEGF and matrix metalloproteinases (MMPs) (Rohan et al. 2014). High levels of coinhibitory immune checkpoint ligands, such as PD-L1, programmed death-ligand 2 (PD-L2), and costimulatory ligands, CD80 and CD86, expressed on TAMs inhibit NK cells and CTLs (Noy and Pollard 2014; Cassetta and Kitamura 2018).

Chronic inflammation of advanced tumor induces differentiation of myeloid precursor cells into gMDSCs, a major type of immune suppressive cells in the TME. gMDSCs not only differentiate into TAMs but also enhance 
immunosuppressive macrophages polarity of nearby TAMs by secreting IL-10 (Kumar et al. 2016). In addition, gMDSCs play a critical role in depleting T cells in the TME and interfering with T-cell trafficking into tumors by cleaving Lselectin, an important adhesion molecule in Tcell extravasation (Hanson et al. 2009). Furthermore, various coinhibitory checkpoint molecules, in particular, Gal-9, which induces apoptosis of $\mathrm{TIM}^{+}$-exhausted $\mathrm{T}$ cells, are highly expressed in gMDSCs (Anderson 2014). In total, such accumulation of malignant properties and immune malfunction in the TME allows cancer cells to disseminate from the primary tumor site and those that survive in the circulatory system to settle in a metastatic niche, eventually forming metastatic tumors.

\section{Current Cancer Immunotherapy}

The establishment of an antitumor immune response and memory not only eliminates tumor cells and prevents recurrence in the primary region but also inhibits metastasis to distant sites. Increasing the systemic immune response and normalizing immunosurveillance within the TME are two major strategies for the development of cancer immunotherapy (Mellman et al. 2011; Pardoll 2012; Mahoney et al. 2015; Sharma et al. 2017; Sanmamed and Chen 2018). To date, four different immunotherapies are approved by the FDA or are in clinical trials, all of which focus on boosting immune response and immune cell activities in the TME and have demonstrated profound clinical benefits in cancer patients. Below, we briefly describe each of these strategies.

\section{Cytokine Therapy}

In the TME, multiple cytokines are required for immune cells to maintain their growth, activation, and ability to infiltrate into the tumor regions. In particular, the administration of IL-2 induces significant antitumor effects and reduces metastatic tumor progression in murine tumor models (Rosenberg et al. 1985). IL-2 therapy was subsequently approved by the FDA in 1992 for the treatment of renal cell carcinoma and mela- noma, achieving a $15 \%-29 \%$ response rate in different studies (Table 1; Rosenberg 2014).

IL-2 is also required for the expansion and promotion of activated T cells, and a high dose of IL-2 has been shown to induce an antitumor immune response in a certain population of cancer patients (Jiang et al. 2016). However, some side effects of high-dose IL-2, including significant toxicity in multiple organs and tissues, hypotension, and capillary leak syndrome, have been reported (Atkins et al. 1999; Rosenberg 2014). In 2016, Jiang et al. (2016) described a low-dose IL-2 treatment coupled with ACT therapy (see later section) with promising clinical benefits in cancer patients. To avoid the side effects of IL-2, orthogonal IL-2 cytokine-receptor complexes in which IL-2 interacts only with the matched IL-2 receptor on CAR-T or CARNK cells and induces less toxicity in other organs with normal IL-2 receptor have been proposed as the next-generation ACT therapy (Sockolosky et al. 2018).

\section{Cancer Vaccines}

The recognition of abnormal or transformed cells by immune cells is a key step in cancer immunosurveillance (Hollingsworth and Jansen 2019). T-cell tracking, infiltration, and activation via the TCR signaling pathway are required to identify tumor neoantigens expressed on cancer cells (Chen and Mellman 2013). However, during tumorigenesis, cancer cells silence the neoantigen exposure to reduce immunogenicity, which attenuates the presence of immune cells in the TME (also referred to as cold condition). By administering vaccines based on tumor antigens, immunosurveillance can be reactivated by increasing infiltrated immune cells at the tumor regions (also referred to as hot condition) (Galon and Bruni 2019).

Ideally, the antigens used in cancer vaccines are designed to achieve four goals: those that are (1) specifically expressed by cancer cells; (2) present on a broad range of cancer types; (3) required for cancer cell survival; and (4) highly immunogenic (Hollingsworth and Jansen 2019). Not all antigens can meet these goals but can still significantly activate the anticancer immune re- 
J.-H. Cha et al.

Table 1. Current immunotherapies approved by the FDA

\begin{tabular}{|c|c|c|c|c|}
\hline Approach & Target & Name & Company & Diseases \\
\hline $\begin{array}{l}\text { Cytokine } \\
\text { (IL-2) }\end{array}$ & IL-2R & Proleukin (Aldesleukin) & $\begin{array}{l}\text { Prometheus } \\
\text { Laboratories Inc. }\end{array}$ & $\begin{array}{l}\text { Renal cell carcinoma, and } \\
\text { melanoma }\end{array}$ \\
\hline DC vaccine & PAP & Sipuleucel-T (Provenge) & $\begin{array}{l}\text { Dendreon } \\
\text { Corporation }\end{array}$ & Prostate cancer \\
\hline \multirow{7}{*}{$\begin{array}{l}\text { Immune } \\
\text { checkpoint } \\
\text { blockade }\end{array}$} & CTLA-4 & Ipilimumab (Yervoy) & $\begin{array}{l}\text { Bristol-Myers } \\
\text { Squibb }\end{array}$ & $\begin{array}{l}\text { Melanoma, renal cell carcinoma, } \\
\text { and colorectal cancer }\end{array}$ \\
\hline & PD-1 & Nivolumab (Opdivo) & $\begin{array}{l}\text { Bristol-Myers } \\
\text { Squibb }\end{array}$ & $\begin{array}{l}\text { Melanoma, non-small-cell lung } \\
\text { cancer, renal cell carcinoma, } \\
\text { Hodgkin's lymphoma, head and } \\
\text { neck cancer, urothelial } \\
\text { carcinoma, colorectal cancer, } \\
\text { hepatocellular carcinoma, and } \\
\text { small cell lung cancer }\end{array}$ \\
\hline & & $\begin{array}{c}\text { Pembrolizumab } \\
\text { (Keytruda) }\end{array}$ & Merck & $\begin{array}{l}\text { Melanoma, non-small-cell lung } \\
\text { cancer, head and neck cancer, } \\
\text { Hodgkin's lymphoma, urothelial } \\
\text { carcinoma, gastric cancer, } \\
\text { cervical cancer, hepatocellular } \\
\text { carcinoma, and Merkel cell } \\
\text { carcinoma }\end{array}$ \\
\hline & & Cemiplimab (Libtayo) & Regeneron & $\begin{array}{l}\text { Metastatic cutaneous squamous cell } \\
\text { carcinoma }\end{array}$ \\
\hline & PD-L1 & $\begin{array}{r}\text { Atezolizumab } \\
\text { (Tecentriq) }\end{array}$ & Genentech & $\begin{array}{l}\text { Bladder cancer, non-small-cell lung } \\
\text { cancer, triple-negative breast } \\
\text { cancer, and small cell lung cancer }\end{array}$ \\
\hline & & Avelumab (Bavencio) & $\begin{array}{l}\text { Merck Serono and } \\
\text { Pfizer }\end{array}$ & $\begin{array}{l}\text { Merkel cell carcinoma, urothelial } \\
\text { carcinoma }\end{array}$ \\
\hline & & Durvalumab (Imfinzi) & AstraZeneca & $\begin{array}{l}\text { Urothelial carcinoma, non-small- } \\
\text { cell lung cancer }\end{array}$ \\
\hline \multirow[t]{2}{*}{$\begin{array}{l}\text { CAR T-cell } \\
\text { therapy }\end{array}$} & CD19 & $\begin{array}{l}\text { Axicabtagene ciloleucel } \\
\text { (Yescarta) }\end{array}$ & Kite Pharma & Large B-cell lymphoma \\
\hline & & $\begin{array}{l}\text { Tisagenlecleucel } \\
\text { (Kymriah) }\end{array}$ & Novartis & $\begin{array}{l}\text { Acute lymphoblastic leukemia, and } \\
\text { large B-cell lymphoma }\end{array}$ \\
\hline
\end{tabular}

Data from FDA website (before 2019 April).

DC, dendritic cells; PAP, prostatic acid phosphatase.

sponse in cancer patients. To date, tumor-associated antigens and oncogenic viral antigens are the major candidates for cancer vaccines. $\mathrm{Tu}$ mor-associated antigens, which are self-proteins but abnormally expressed by cancer cells (Hollingsworth and Jansen 2019), include overexpressed surface oncogenes, for example, HER2 (Disis et al. 2009), cell lineage differentiation antigens, for example, prostate-specific antigen (Correale et al. 1997), and other common mutations, for example, $B C R-A B L 1$ gene fusion (Finn 2018). In addition to tumor-associated antigens, oncogenic viral antigens are also molecular driv- ers of oncogenesis that are highly immunogenic. Furthermore, around $16 \%$ of human cancers are related to viral infection (de Martel et al. 2012), implying that oncogenic viral antigen-based vaccines can prevent tumorigenesis. For example, hepatitis B virus (HBV) infection is one of the major risk factors contributing to the development of HCC, and the implementation of the HBV immunization program has reduced the occurrence of hepatocellular carcinoma (HCC) prevention in many Asian countries (Chang et al. 2009; Llovet et al. 2016). Likewise, vaccines against the human papilloma virus (HPV) also 
provide protection against HPV infection and associated precancerous lesions (Ault and $\mathrm{Fu}$ ture 2007; Paavonen et al. 2009).

Currently, the specificity and efficacy of immune cell activation by cancer antigen presentation rely on several platforms: cellular, viral vector, and DNA/RNA vaccines. For example, the FDA-approved cell-based immunotherapy sipuleucel-T vaccine (Provenge) provides a 4mo increase in median survival of patients with metastatic castration-resistant prostate cancer (Table 1; Kantoff et al. 2010). Specifically, Provenge consists of autologous peripheral blood mononuclear cells (PBMCs) isolated by leukapheresis from patients and DCs activated by prostate antigen and granulocyte-macrophage colony-stimulating factor (GM-CSF) (Bol et al. 2016). Moreover, increased progression-free and overall survival were observed in several clinical trials using glioma tumor lysateloaded DCs. These results suggested that DC vaccines are effective cell-based immunotherapy (Anguille et al. 2014; Van Gool 2015).

\section{Immune Checkpoint Blockade (ICB)}

Activation of immune cells is tightly controlled by ligand-receptor interactions between immune cells or immune cells and tumor cells. Tcell activation is initiated via neoantigen recognition by the TCR and regulated by costimulatory and inhibitory signals from immune checkpoint molecules (Pardoll 2012). The intricate balance between costimulatory and coinhibitory signaling is critical to prevent autoimmune responses and maintain immunosurveillance under normal physiological conditions. However, cancer cells can tip the balance by amplifying coinhibitory molecules signaling and/or reducing costimulatory signaling, which can hamper anti-immune response and provide a niche for cancer immune evasion (Pardoll 2012; Topalian et al. 2015). Targeting immune checkpoints by specific antibodies to restore immunosurveillance has demonstrated promising clinical outcomes in cancer treatment.

CTLA-4/B7-1 and PD-1/PD-L1 are two major immune checkpoints that inhibit T-cell activation during the priming and effector phase, respectively (Chen and Mellman 2013). Mechanistically, the interactions between CTLA-4 and B7-1, and PD-1 and PD-L1 enhance the activities of protein phosphatase 2 (PP2A) and Src homology region 2 domain-containing phosphatases (SPH2), respectively, leading to down-regulation of the TCR pathway and inhibition of T-cell activities (Schildberg et al. 2016). As a result, several antibodies against those immune checkpoints, including ipilimumab (CTLA-4), nivolumab, pembrolizumab and cemiplimab (PD-1), and atezolizumab, avelumab, and durvalumab (PD-L1), were developed and are now approved by the FDA for the treatment of multiple solid tumors (Table 1). The response rates of a single immune checkpoint inhibitor are in the range of $10 \%-45 \%$ depending on the cancer types (Sharma and Allison 2015; Zou et al. 2016). Blockade of several coinhibitory receptors and ligands, such as LAG-3 (ligands: class II MHC and fibrinogen-like protein 1) ( $\mathrm{Li}$ et al. 2013; Wang et al. 2019) and TIM-3 (ligand: Gal-9) (Li et al. 2012), have demonstrated significant antitumor effects in clinical trials. In patients with advanced melanoma receiving nivolumab-plus-ipilimumab, the 3-yr overall survival rate was $58 \%$ (Wolchok et al. 2017). This finding is highly encouraging and provides a great opportunity to improve therapeutic efficacy based on the current success of immune checkpoint therapy by elucidating the mechanisms underlying immune checkpoint biosynthesis.

Along the same line, impressive efficacy of combination therapies involving anti-immune checkpoints in clinical trials and preclinical studies have been reported. For example, the expression of coinhibitory molecule, for example, PD-L1 or PD-1, in tumor microenvironment is tightly controlled by posttranslational modifications, such as glycosylation, palmitoylation, and ubiquitination (Li et al. 2016, 2019; Lim et al. 2016; Cha et al. 2018; Hsu et al. 2018; Meng et al. 2018; Yang et al. 2019; Yao et al. 2019). Our most recent work identified another regulatory mechanism underlying $\mathrm{PD}-\mathrm{L} 1$ protein stability via the IL-6/Janus kinase 1 (JAK1) signaling axis (Chan et al. 2019). Preclinical studies targeting posttranslational mod- 
J.-H. Cha et al.

ifications and coinhibitory molecule expression regulation in the TME by inhibitors have revealed promising combination therapies, such as CDK4/6 inhibitor plus anti-PD-1 (Goel et al. 2017) and metformin plus anti-CTLA-4 (Cha et al. 2018). Several recent studies demonstrated that exosomal PD-L1 suppresses T-cell activity and down-regulates antitumor immunity (Yang et al. 2018; Poggio et al. 2019; Yao et al. 2019). The authors of those studies further suggested that exosomal immune checkpoints establish a premetastatic niche in distant organs by suppressing systemic immunosurveillance and memory. Together, the blockade of immune checkpoint function is a reliable strategy to inhibit local tumor progression and systemic metastasis.

\section{Adoptive Cell Transfer (ACT) Therapy}

ACT was developed as cancer treatment based on the concept of using tumor-reactive immune cells to eradicate tumor cells expressing specific surface markers (Rosenberg and Restifo 2015). The $\mathrm{T}$ cell population is a major candidate for this type of precise cell-based immunotherapy.

Generally, there are two strategies for T-cell transfer therapy. First, tumor-infiltrating lymphocytes (TILs) are isolated from a patient's tumor and expanded ex vivo with $\mathrm{T}$ cell-activating cytokines, for example, IL-2. The reactivated TILs are then reinfused into the same patient along with cytokines to expand and promote activation of T cells against tumor cells (Rosenberg and Restifo 2015). One of the main limitations of using this approach is that a majority of cancer patients are already with lymphodepletion after radiotherapy or chemotherapy, causing insufficient T-cell population for ex vivo expansion (Rosenberg et al. 2011). Second, the isolated autologous T cells are engineered to express CARs that recognize tumor cells with a specific marker. CARs possess both the extracellular domain of antigen-specific single-chain variable fragment $(\mathrm{scFv})$ and the intracellular domain of costimulatory receptor, such as CD28 and/or CD137 (Sanmamed and Chen 2018; O’Donnell et al. 2019). Therefore, CAR $\mathrm{T}$ cells are not restricted by neoantigen peptides presented on the MHC for activation and recognition of cancer cells (O'Donnell et al. 2019).

In several clinical trials, CAR $\mathrm{T}$ cells that target CD19-expressing cancer cells have demonstrated considerable effectiveness on destroying hematological malignant cells, including $\mathrm{B}$ cell lymphoma, non-Hodgkin's lymphoma (Kochenderfer et al. 2010), and chronic lymphocytic leukemia (Porter et al. 2011). Other studies have also reported a $25 \%-90 \%$ response rate of CAR $\mathrm{T}$-cell therapy in different hematological malignancies (Brentjens et al. 2013; Grupp et al. 2013).

Those encouraging results led to the accelerated approval of CD19 CAR T-cell therapy (Kymriah and Yescarta) in 2017 (Table 1). The efficacy of CAR T-cell therapy for solid tumors, however, warrants further investigation (D'Aloia et al. 2018). Unlike hematological malignancies, surface markers on solid tumors are highly diverse due to their origin, and this poses a major challenge in developing specific targeted CAR T-cell therapy.

CAR T-cell therapy also requires the collection and gene transduction of autologous $\mathrm{T}$ cells from patients, a process that can be time-consuming and inefficient. Furthermore, lymphodepletion also limits the number of patients eligible for this type of therapy (Li et al. 2018b). Different from T cells, NK cells mediate their tumor-killing effects without requiring matched human leukocyte antigen (HLA) (Morvan and Lanier 2016), suggesting the utility of NK cells from other sources for ACT therapy (Guillerey et al. 2016). In this regard, a recent study indicated that NK cells derived from human induced pluripotent stem cells (iPSC)s expressing CAR may be considered as another ACT therapy ( $\mathrm{Li}$ et al. 2018b). Given that engineered NK cells can be generated without any limits through differentiation from iPSCs, this strategy may provide an affordable and timely cell-based cancer immunotherapy.

\section{Perspectives on Cancer Immunotherapy}

Several clinical trials have revealed a strong positive correlation between prognosis after ICB or ACT therapy and the number and activity of 
TILs (Svane and Verdegaal 2014). The efficacy in eliminating the primary tumor and preventing metastatic recurrence has the potential to be greatly improved if an immune suppressed or "cold" tumor (low TIL population) can be converted into an inflamed or "hot" tumor (high TIL population). To this end, various approaches are ongoing to establish a TME that is friendly to T-cell immunity. Moreover, recent studies on gut microbiota suggested a new paradigm in antitumor immunity (Fig. 2).

\section{Direct Enhancement of T-Cell Immunity}

Because antigen presentation is a prerequisite of $\mathrm{T}$-cell homing to tumor tissues, boosting the antigen-presenting cell (APC) activity is expected to increase the TIL population and activation. Indeed, cold tumors with low T-cell immunity exhibit lower APC activity (Bonaventura et al. 2019) compared with hot tumors. In an animal model of glioma, a major type of cold tumor, Lynes and colleagues found that the efficacy of current ICB/ACT therapy is substantially increased when APC activity is boosted by DC vaccines or oncolytic viruses (Lynes et al. 2018).

In addition to increasing the APC activity, TGF- $\beta$ signaling is also an attractive target to enhance T-cell immunity. TGF- $\beta$ is a driver of tumor progression and metastasis (Massagué 2012), and is considered as one of the determinants that prevents immunosurveillance and contributes to poor response to PD-1/PD-L1 blockade in cancer patients (Ganesh and Massagué 2018). Mechanistically, TGF- $\beta$ released from carcinoma-associated fibroblasts (CAFs) can limit TIL activity. Therefore, blocking TGF- $\beta$ signaling by antibodies or inhibitors could induce cold-to-hot tumor conversion. Because TGF- $\beta$ signaling is also critical for maintaining metastatic niche, Tauriello et al. investigated the combined inhibition of TGF- $\beta$ and PD-L1. Indeed, the authors demonstrated that combined inhibition of TGF- $\beta$ and PD-L1 eliminated established metastases in a preclinical mouse model of colorectal cancer (Tauriello et al. 2018). A bispecific antibody against PD$\mathrm{L} 1$ and TGF- $\beta$ receptor has since been developed to achieve this dual blockade (Lan et al. 2018).

Multiples studies by $\mathrm{Li}$ and coworkers revealed a critical role of $\mathrm{N}$-linked glycosylation of immune checkpoints for the ligand/receptor interactions (Li et al. 2018a). Specifically, Nlinked glycosylation of immune checkpoints, for example, PD-L1, is required to maintain their protein stability ( $\mathrm{Li}$ et al. 2016, 2018a; Cha et al. 2018; Hsu et al. 2018). On the basis of those findings, inhibitors that block N-glycosylation modification on immune checkpoints in combination with immunotherapies may achieve better response rates than single agent alone. Furthermore, aberrant glycosylation of proteins on cancer cells enhances cancer immune evasion, EMT, tumor cell dissociation and invasion, cell-matrix interactions, and metastasis (Pinho and Reis 2015; Rodríguez et al. 2018). Notably, blocking the biosynthesis of specific glycan structure of adhesion molecules on tumor cells reduces cancer metastasis (Agrawal et al. 2017). Thus, if these molecular pathways
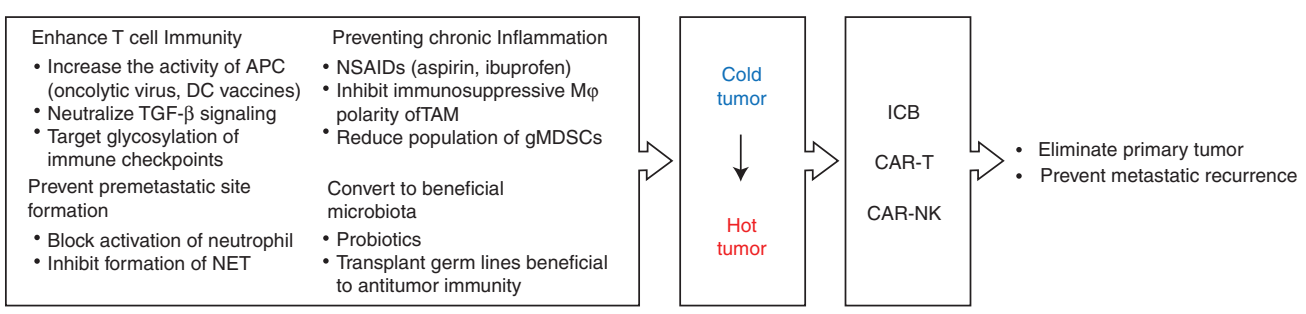

Figure 2. Perspectives in cancer immunotherapy. The conversion of "cold" tumor (low TIL population) to "hot" tumor (high TIL population) has the potential to improve the efficacy of current immune therapy. Various approaches to establish a TME that is friendly to T-cell immunity may be considered, such as by combining current ICB and ACT therapy. 
J.-H. Cha et al.

are also involved in cancer metastasis by regulating aberrant biosynthesis of glycosylated molecules, the combination strategy targeting glycosylation and immune checkpoints may also improve the clinical benefits and prevent metastasis in cancer patients.

\section{Preventing Chronic Inflammation}

Treatment of chronic inflammation before and/ or after cancer therapy is important to maintaining T-cell immunity as chronic exposure to inflammatory cytokines increases the gMDSC population in the blood and tumor tissues (Wang and DuBois 2015). gMDSCs inhibit Tcell immunity not only directly through the expression of the coinhibitory checkpoints and inhibitory cytokines but also indirectly by increasing the population of the T-cell immunity suppressors, immunosuppressive TAMs and T regs (Kumar et al. 2016). Such immunosuppression induced by chronic inflammation can promote cancer cell survival in the circulatory system and metastatic niche. Removal of primary lesion by surgery or eradication by cytotoxic chemotherapy are the most common approaches in cancer therapy; however, some patients exhibit increased distant metastasis right after surgery or chemotherapy (Smith et al. 2008; Al-Sahaf et al. 2010; Keklikoglou et al. 2019), which may be attributed to inflammation from the surgical wound and tumor-released extracellular vesicles, suggesting that the transient immunosuppressive state following these therapies creates a niche for cancer cell metastasis. In this regard, a regimen of nonsteroidal anti-inflammatory drugs (NSAIDs), such as aspirin, celecoxib, and ibuprofen, after surgery may have some benefits in maintaining antitumor T-cell immunity. Indeed, several meta-analyses indicated NSAIDs can reduce the metastatic recurrence of various cancer types (Elwood et al. 2016; Zhao et al. 2017). Furthermore, a recent study also indicated that preoperative administration of NSAIDs further enhances anticancer T-cell immunity unleashed by immune checkpoint blockade and eradicates micrometastases (Panigrahy et al. 2019). Therefore, the addition of NSAIDs to immunotherapy has the potential to improve the therapeutic efficacy and reduce metastasis.

\section{Preventing Premetastatic Site Formation}

Tumor metastasis relies on cancer cells (the "seeds"), which disseminate from the primary region by escaping immunosurveillance and specific organ microenvironment (the "soil") (Fidler 2003). Moreover, the appropriate distant microenvironment is critical for attachment, growth, and colonization of metastatic cancer cells. Targeting either the seeds or soil provides an opportunity to block the progression of cancer metastasis. Interestingly, leukocyte composition at specific organ microenvironment and neutrophil-derived leukotrienes from premetastatic regions have been shown to favor the colonization of metastatic cancer cells (Wculek and Malanchi 2015). Recently, Albrengues et al. revealed that neutrophil extracellular traps (NETs) promote lung metastases under chronic inflammation by awakening dormant cancer cells through NET-mediated ECM remodeling. Indeed, a therapeutic antibody targeting such ECM remodeling has been shown to effectively suppress lung metastases in a breast cancer animal model (Albrengues et al. 2018). Consistent with these observations, Lee et al. (2019) also demonstrated that activated neutrophils form NETs and establish a premetastatic niche of ovarian cancer in the omentum. Together, those findings suggested that pharmacological inhibition of leukotrienes has the potential to abrogate prometastatic establishment and subsequent metastasis.

\section{Beneficial Microbiota}

There is accumulating evidence to support the association between antitumor immunity and gut microbiota. Recently, three different groups reported that the gut microbiota critically affects the efficacy of PD-L1/PD-1 therapies in metastatic melanoma and non-small-cell lung cancer preclinical models (Gopalakrishnan et al. 2018; Matson et al. 2018; Routy et al. 2018). The authors reported better PD-L1/PD-1 therapeutic efficacy in tumor-bearing mice transplanted 
with feces from IBC responders than those with fecal implantation from nonresponders. Consistent with these observations, fecal microbiota transplantation (FMT) in IBC responders improved T-cell immunity, suggesting a critical role of the gut microbiota in adaptive immunity against tumors. Each group identified the specific beneficial germline that enhances immunotherapy: (1) Faecalibacterium prausnitzii (Gopalakrishnan et al. 2018); (2) Bifidobacterium longum (Matson et al. 2018); and (3) Akkermansia muciniphila (Routy et al. 2018). It would be worthwhile to further investigate the mechanisms underlying the beneficial effects of gut bacteria or FMT in immunotherapy.

\section{CONCLUDING REMARKS}

In recent decades, harnessing and renormalizing immune response in cancer patients have provided an enormous clinical impact and ignited the discovery of new cancer immunotherapies. Unlike targeting tumor cells directly, multiple processes, such as neoantigen recognition, immune cell activation, and immune cell infiltration, are required to establish a successful anticancer immune response. The immune system in a majority of cancer patients suffers from systematic destruction during tumor progression and the loss of balanced immunosurveillance. As described in this review, although singleagent immunotherapy has demonstrated promising results in certain cancer types, improvement of the response rates in others is necessary. Given that a multitude of factors influence antitumor immunity, enhancing or restoring one of the many immune response processes cannot compensate for malfunctions in others, which partly explains why single-agent immunotherapy has not been shown to sufficiently conquer cancer immune escape and overcome subsequent cancer metastasis. In this regard, combining immunotherapy with activation of different steps of immunosurveillance may restore antitumor immunity in cancer patients. The diversity of immune cell profiles in different cancer patients is another challenge in current immunotherapy. Defining the immune profiles in individual cancer patients by using biomarkers indicative of immune evasion may reveal more efficient combination therapies. The knowledge of current immuno-oncology and those yet to be discovered will expand the frontiers of immunotherapy and benefit more cancer patients in the near future.

\section{ACKNOWLEDGMENTS}

This work was funded in part by the following: National Institutes of Health (CCSG CA016672, R01 CA211615, and U01 CA201777); Cancer Prevention \& Research Institute of Texas (MIRA grant RP160710); National Breast Cancer Foundation, Inc.; Breast Cancer Research Foundation (BCRF-17-069); Patel Memorial Breast Cancer Endowment Fund; The University of Texas MD Anderson-China Medical University and Hospital Sister Institution Fund; Center for Biological Pathways; Ministry of Health and Welfare, China Medical University Hospital Cancer Research Center of Excellence $(\mathrm{MOH}$ W108-TDU-B-212-122015 and MOHW108TDU-B-212-124024; Inha University Institution Fund [to J.-H. C.]).

\section{REFERENCES}

Agrawal P, Fontanals-Cirera B, Sokolova E, Jacob S, Vaiana CA, Argibay D, Davalos V, McDermott M, Nayak S, Darvishian F, et al. 2017. A systems biology approach identifies FUT8 as a driver of melanoma metastasis. Cancer Cell 31: 804-819.e7. doi:10.1016/j.ccell.2017.05.007

Akbay EA, Koyama S, Carretero J, Altabef A, Tchaicha JH, Christensen CL, Mikse OR, Cherniack AD, Beauchamp EM, Pugh TJ, et al. 2013. Activation of the PD-1 pathway contributes to immune escape in EGFR-driven lung tumors. Cancer Discov 3: 1355-1363. doi:10.1158/21598290.CD-13-0310

Albrengues J, Shields MA, Ng D, Park CG, Ambrico A, Poindexter ME, Upadhyay P, Uyeminami DL, Pommier A, Küttner V, et al. 2018. Neutrophil extracellular traps produced during inflammation awaken dormant cancer cells in mice. Science 361: eaao4227. doi:10.1126/science .aao4227

Al-Sahaf O, Wang JH, Browne TJ, Cotter TG, Redmond HP. 2010. Surgical injury enhances the expression of genes that mediate breast cancer metastasis to the lung. Ann Surg 252: 1037-1043. doi:10.1097/SLA.0b013e3181ef c635

Anderson AC. 2014. Tim-3: an emerging target in the cancer immunotherapy landscape. Cancer Immunol Res 2: 393 398. doi:10.1158/2326-6066.CIR-14-0039 
J.-H. Cha et al.

Anguille S, Smits EL, Lion E, van Tendeloo VF, Berneman ZN. 2014. Clinical use of dendritic cells for cancer therapy. Lancet Oncol 15: e257-e267. doi:10.1016/S14702045(13)70585-0

Antonia S, Goldberg SB, Balmanoukian A, Chaft JE, Sanborn RE, Gupta A, Narwal R, Steele K, Gu Y, Karakunnel JJ, et al. 2016. Safety and antitumour activity of durvalumab plus tremelimumab in non-small cell lung cancer: a multicentre, phase 1b study. Lancet Oncol 17: 299-308. doi:10.1016/S1470-2045(15)00544-6

Armand P, Nagler A, Weller EA, Devine SM, Avigan DE, Chen YB, Kaminski MS, Holland HK, Winter JN, Mason JR, et al. 2013. Disabling immune tolerance by programmed death-1 blockade with pidilizumab after autologous hematopoietic stem-cell transplantation for diffuse large B-cell lymphoma: results of an international phase II trial. J Clin Oncol 31: 4199-4206. doi:10.1200/JCO.2012 .48 .3685

Armitage P. 1985. Multistage models of carcinogenesis. Environ Health Perspect 63: 195-201. doi:10.1289/ehp .8563195

Atkins MB, Lotze MT, Dutcher JP, Fisher RI, Weiss G, Margolin K, Abrams J, Sznol M, Parkinson D, Hawkins M, et al. 1999. High-dose recombinant interleukin 2 therapy for patients with metastatic melanoma: analysis of $270 \mathrm{pa}$ tients treated between 1985 and 1993. J Clin Oncol 17: 2105-2116. doi:10.1200/JCO.1999.17.7.2105

Ault KA, Future II Study Group. 2007. Effect of prophylactic human papillomavirus L1 virus-like-particle vaccine on risk of cervical intraepithelial neoplasia grade 2 , grade 3 , and adenocarcinoma in situ: a combined analysis of four randomised clinical trials. Lancet 369: 1861-1868. doi:10 .1016/S0140-6736(07)60852-6

Balkwill FR, Capasso M, Hagemann T. 2012. The tumor microenvironment at a glance. J Cell Sci 125: 55915596. doi:10.1242/jcs.116392

Barcellos-Hoff MH, Lyden D, Wang TC. 2013. The evolution of the cancer niche during multistage carcinogenesis. Nat Rev Cancer 13: 511-518. doi:10.1038/nrc3536

Basu AK. 2018. DNA damage, mutagenesis and cancer. Int $J$ Mol Sci 19: 970. doi:10.3390/ijms19040970

Bellora F, Castriconi R, Dondero A, Reggiardo G, Moretta L, Mantovani A, Moretta A, Bottino C. 2010. The interaction of human natural killer cells with either unpolarized or polarized macrophages results in different functional outcomes. Proc Natl Acad Sci 107: 21659-21664. doi:10 $.1073 /$ pnas. 1007654108

Bol KF, Schreibelt G, Gerritsen WR, de Vries IJ, Figdor CG. 2016. Dendritic cell-based immunotherapy: state of the art and beyond. Clin Cancer Res 22: 1897-1906. doi:10 .1158/1078-0432.CCR-15-1399

Bonaventura P, Shekarian T, Alcazer V, Valladeau-Guilemond J, Valsesia-Wittmann S, Amigorena S, Caux C, Depil S. 2019. Cold tumors: a therapeutic challenge for immunotherapy. Front Immunol 10: 168. doi:10.3389/ fimmu.2019.00168

Braumüller H, Wieder T, Brenner E, Aßmann S, Hahn M, Alkhaled M, Schilbach K, Essmann F, Kneilling M, Griessinger C, et al. 2013. T-helper-1-cell cytokines drive cancer into senescence. Nature 494: 361-365. doi:10.1038/ nature11824
Brentjens RJ, Davila ML, Riviere I, Park J, Wang X, Cowell LG, Bartido S, Stefanski J, Taylor C, Olszewska M, et al. 2013. CD19-targeted T cells rapidly induce molecular remissions in adults with chemotherapy-refractory acute lymphoblastic leukemia. Sci Transl Med 5: 177 ra38. doi:10.1126/scitranslmed.3005930

Casey SC, Tong L, Li Y, Do R, Walz S, Fitzgerald KN, Gouw AM, Baylot V, Gutgemann I, Eilers M, et al. 2016. MYC regulates the antitumor immune response through $\mathrm{CD} 47$ and PD-L1. Science 352: 227-231. doi:10.1126/science .aac9935

Cassetta L, Kitamura T. 2018. Targeting tumor-associated macrophages as a potential strategy to enhance the response to immune checkpoint inhibitors. Front Cell Dev Biol 6: 38. doi:10.3389/fcell.2018.00038

Cha JH, Yang WH, Xia W, Wei Y, Chan LC, Lim SO, Li CW, Kim T, Chang SS, Lee HH, et al. 2018. Metformin promotes antitumor immunity via endoplasmic-reticulumassociated degradation of PD-L1. Mol Cell 71: 606-620. e7. doi:10.1016/j.molcel.2018.07.030

Chan LC, Li CW, Xia W, Hsu JM, Lee HH, Cha JH, Wang HL, Yang WH, Yen EY, Chang WC, et al. 2019. IL-6/JAK1 pathway drives PD-L1 Y112 phosphorylation to promote cancer immune evasion. J Clin Invest 129: 3324-3338. doi:10.1172/JCI126022

Chang MH, You SL, Chen CJ, Liu CJ, Lee CM, Lin SM, Chu HC, Wu TC, Yang SS, Kuo HS, et al. 2009. Decreased incidence of hepatocellular carcinoma in hepatitis $B$ vaccinees: a 20-year follow-up study. J Natl Cancer Inst 101: 1348-1355. doi:10.1093/jnci/djp288

Chaudhary B, Elkord E. 2016. Regulatory T cells in the tumor microenvironment and cancer progression: role and therapeutic targeting. Vaccines (Basel) 4: 28. doi:10.3390/ vaccines 4030028

Chen DS, Mellman I. 2013. Oncology meets immunology: the cancer-immunity cycle. Immunity 39: 1-10. doi:10 $.1016 /$ j.immuni.2013.07.012

Coelho MA, de Carné Trécesson S, Rana S, Zecchin D, Moore C, Molina-Arcas M, East P, Spencer-Dene B, Nye E, Barnouin K, et al. 2017. Oncogenic RAS signaling promotes tumor immunoresistance by stabilizing PD-L1 mRNA. Immunity 47: 1083-1099.e6. doi:10.1016/j .immuni.2017.11.016

Correale P, Walmsley K, Nieroda C, Zaremba S, Zhu M, Schlom J, Tsang KY. 1997. In vitro generation of human cytotoxic $\mathrm{T}$ lymphocytes specific for peptides derived from prostate-specific antigen. $J$ Natl Cancer Inst 89: 293-300. doi:10.1093/jnci/89.4.293

D’Aloia MM, Zizzari IG, Sacchetti B, Pierelli L, Alimandi M. 2018. CAR-T cells: the long and winding road to solid tumors. Cell Death Dis 9: 282. doi:10.1038/s41419-0180278-6

de Martel C, Ferlay J, Franceschi S, Vignat J, Bray F, Forman D, Plummer M. 2012. Global burden of cancers attributable to infections in 2008: a review and synthetic analysis Lancet Oncol 13: 607-615. doi:10.1016/S1470-2045(12) 70137-7

Disis ML, Wallace DR, Gooley TA, Dang Y, Slota M, Lu H, Coveler AL, Childs JS, Higgins DM, Fintak PA, et al. 2009. Concurrent trastuzumab and HER2/neu-specific vaccination in patients with metastatic breast cancer. J Clin Oncol 27: 4685-4692. doi:10.1200/JCO.2008.20.6789 
Dunn GP, Bruce AT, Ikeda H, Old LJ, Schreiber RD. 2002 Cancer immunoediting: from immunosurveillance to tumor escape. Nat Immunol 3: 991-998. doi:10.1038/ nil102-991

Dwivedi A, Karulkar A, Ghosh S, Rafiq A, Purwar R. 2019. Lymphocytes in cellular therapy: functional regulation of CAR T cells. Front Immunol 9: 3180. doi:10.3389/fimmu .2018 .03180

Elwood PC, Morgan G, Pickering JE, Galante J, Weightman AL, Morris D, Kelson M, Dolwani S. 2016. Aspirin in the treatment of cancer: reductions in metastatic spread and in mortality: a systematic review and meta-analyses of published studies. PLoS One 11: e0152402. doi:10.1371/ journal.pone. 0152402

Fidler IJ. 2003. The pathogenesis of cancer metastasis: the 'seed and soil' hypothesis revisited. Nat Rev Cancer 3: 453-458. doi:10.1038/nrc1098

Finn OJ. 2018. The dawn of vaccines for cancer prevention. Nat Rev Immunol 18: 183-194. doi:10.1038/nri.2017.140

Gajewski TF, Schreiber H, Fu YX. 2013. Innate and adaptive immune cells in the tumor microenvironment. Nat Immunol 14: 1014-1022. doi:10.1038/ni.2703

Galon J, Bruni D. 2019. Approaches to treat immune hot, altered and cold tumours with combination immunotherapies. Nat Rev Drug Discov 18: 197-218. doi:10 .1038/s41573-018-0007-y

Ganesh K, Massagué J. 2018. TGF- $\beta$ inhibition and immunotherapy: checkmate. Immunity 48: 626-628. doi:10 .1016/j.immuni.2018.03.037

Gauci ML, Lanoy E, Champiat S, Caramella C, Ammari S, Aspeslagh S, Varga A, Baldini C, Bahleda R, Gazzah A, et al. 2019. Long-term survival in patients responding to anti-PD-1/PD-L1 therapy and disease outcome upon treatment discontinuation. Clin Cancer Res 25: 946956. doi:10.1158/1078-0432.CCR-18-0793

Goel S, DeCristo MJ, Watt AC, BrinJones H, Sceneay J, Li BB, Khan N, Ubellacker JM, Xie S, Metzger-Filho O, et al. 2017. CDK4/6 inhibition triggers anti-tumour immunity. Nature 548: 471-475. doi:10.1038/nature23465

Gopalakrishnan V, Spencer CN, Nezi L, Reuben A, Andrews MC, Karpinets TV, Prieto PA, Vicente D, Hoffman K, Wei SC, et al. 2018. Gut microbiome modulates response to anti-PD-1 immunotherapy in melanoma patients. Science 359: 97-103. doi:10.1126/science.aan 4236

Grossmann KF, Margolin K. 2015. Long-term survival as a treatment benchmark in melanoma: latest results and clinical implications. Ther Adv Med Oncol 7: 181-191. doi:10.1177/1758834015572284

Grupp SA, Kalos M, Barrett D, Aplenc R, Porter DL, Rheingold SR, Teachey DT, Chew A, Hauck B, Wright JF, et al. 2013. Chimeric antigen receptor-modified $\mathrm{T}$ cells for acute lymphoid leukemia. New Engl J Med 368: 15091518. doi:10.1056/NEJMoa1215134

Guillerey C, Huntington ND, Smyth MJ. 2016. Targeting natural killer cells in cancer immunotherapy. Nat Immunol 17: 1025-1036. doi:10.1038/ni.3518

Halenius A, Gerke C, Hengel H. 2015. Classical and nonclassical MHC I molecule manipulation by human cytomegalovirus: so many targets-but how many arrows in the quiver? Cell Mol Immunol 12: 139-153. doi:10.1038/ cmi.2014.105
Hanahan D, Weinberg RA. 2011. Hallmarks of cancer: the next generation. Cell 144: 646-674. doi:10.1016/j.cell .2011 .02 .013

Hanson EM, Clements VK, Sinha P, Ilkovitch D, OstrandRosenberg S. 2009. Myeloid-derived suppressor cells down-regulate L-selectin expression on $\mathrm{CD}^{+}$and $\mathrm{CD} 8^{+}$ T cells. J Immunol 183: 937-944. doi:10.4049/jimmunol .0804253

Harrer DC, Dörrie J, Schaft N. 2018. Chimeric antigen receptors in different cell types: new vehicles join the race. Hum Gene Ther 29: 547-558. doi:10.1089/hum.2017.236

Hollingsworth RE, Jansen K. 2019. Turning the corner on therapeutic cancer vaccines. NPJ Vaccines 4: 7. doi:10 .1038/s41541-019-0103-y

Hsu JM, Xia W, Hsu YH, Chan LC, Yu WH, Cha JH, Chen CT, Liao HW, Kuo CW, Khoo KH, et al. 2018. STT3dependent PD-L1 accumulation on cancer stem cells promotes immune evasion. Nat Commun 9: 1908. doi:10 .1038/s41467-018-04313-6

Jiang T, Zhou C, Ren S. 2016. Role of IL-2 in cancer immunotherapy. OncoImmunology 5: e1163462. doi:10.1080/ 2162402X.2016.1163462

Kantoff PW, Higano CS, Shore ND, Berger ER, Small EJ, Penson DF, Redfern CH, Ferrari AC, Dreicer R, Sims RB, et al. 2010. Sipuleucel-T immunotherapy for castration-resistant prostate cancer. New Engl J Med 363: 411422. doi:10.1056/NEJMoa1001294

Keklikoglou I, Cianciaruso C, Guc E, Squadrito ML, Spring LM, Tazzyman S, Lambein L, Poissonnier A, Ferraro GB, Baer C, et al. 2019. Chemotherapy elicits pro-metastatic extracellular vesicles in breast cancer models. Nat Cell Biol 21: 190-202. doi:10.1038/s41556-018-0256-3

Kim R, Emi M, Tanabe K. 2007. Cancer immunoediting from immune surveillance to immune escape. Immunology 121: 1-14. doi:10.1111/j.1365-2567.2007.02587.x

Kochan G, Escors D, Breckpot K, Guerrero-Setas D. 2013. Role of non-classical MHC class I molecules in cancer immunosuppression. OncoImmunology 2: e26491. doi: 10.4161/onci.26491

Kochenderfer JN, Wilson WH, Janik JE, Dudley ME, StetlerStevenson M, Feldman SA, Maric I, Raffeld M, Nathan DA, Lanier BJ, et al. 2010. Eradication of B-lineage cells and regression of lymphoma in a patient treated with autologous $\mathrm{T}$ cells genetically engineered to recognize CD19. Blood 116: 4099-4102. doi:10.1182/blood-201004-281931

Kumar V, Patel S, Tcyganov E, Gabrilovich DI. 2016. The nature of myeloid-derived suppressor cells in the tumor microenvironment. Trends Immunol 37: 208-220. doi:10 $.1016 /$ j.it.2016.01.004

Lan Y, Zhang D, Xu C, Hance KW, Marelli B, Qi J, Yu H, Qin G, Sircar A, Hernandez VM, et al. 2018. Enhanced preclinical antitumor activity of M7824, a bifunctional fusion protein simultaneously targeting PD-L1 and TGF- $\beta$. Sci Transl Med 10: eaan5488. doi:10.1126/scitranslmed .aan5488

Lee W, Ko SY, Mohamed MS, Kenny HA, Lengyel E, Naora H. 2019. Neutrophils facilitate ovarian cancer premetastatic niche formation in the omentum. J Exp Med 216: 176-194. doi:10.1084/jem.20181170

Leone P, Shin EC, Perosa F, Vacca A, Dammacco F, Racanelli V. 2013. MHC class I antigen processing and presenting 
J.-H. Cha et al.

machinery: organization, function, and defects in tumor cells. J Natl Cancer Inst 105: 1172-1187. doi:10.1093/jnci/ djt184

Li H, Wu K, Tao K, Chen L, Zheng Q, Lu X, Liu J, Shi L, Liu C, Wang G, et al. 2012. Tim-3/galectin-9 signaling pathway mediates $\mathrm{T}$-cell dysfunction and predicts poor prognosis in patients with hepatitis B virus-associated hepatocellular carcinoma. Hepatology 56: 1342-1351. doi:10 $.1002 /$ hep. 25777

Li FJ, Zhang Y, Jin GX, Yao L, Wu DQ. 2013. Expression of LAG-3 is coincident with the impaired effector function of HBV-specific CD8 ${ }^{+} \mathrm{T}$ cell in HCC patients. Immunol Lett 150: 116-122. doi:10.1016/j.imlet.2012.12.004

Li CW, Lim SO, Xia W, Lee HH, Chan LC, Kuo CW, Khoo KH, Chang SS, Cha JH, Kim T, et al. 2016. Glycosylation and stabilization of programmed death ligand-1 suppresses T-cell activity. Nat Commun 7: 12632. doi:10 $.1038 /$ ncomms 12632

Li CW, Lim SO, Chung EM, Kim YS, Park AH, Yao J, Cha JH, Xia W, Chan LC, Kim T, et al. 2018a. Eradication of triple-negative breast cancer cells by targeting glycosylated PD-L1. Cancer Cell 33: 187-201.e10. doi:10.1016/j .ccell.2018.01.009

Li Y, Hermanson DL, Moriarity BS, Kaufman DS. 2018b. Human iPSC-derived natural killer cells engineered with chimeric antigen receptors enhance anti-tumor activity. Cell Stem Cell 23: 181-192.e5. doi:10.1016/j.stem .2018 .06 .002

Li H, Li CW, Li X, Ding Q, Guo L, Liu S, Liu C, Lai CC, Hsu JM, Dong Q, et al. 2019. MET inhibitors promote liver tumor evasion of the immune response by stabilizing PDL1. Gastroenterology 156: 1849-1861.e13. doi:10 $.1053 /$ j.gastro.2019.01.252

Lim SO, Li CW, Xia W, Cha JH, Chan LC, Wu Y, Chang SS, Lin WC, Hsu JM, Hsu YH, et al. 2016. Deubiquitination and stabilization of PD-L1 by CSN5. Cancer Cell 30: 925939. doi:10.1016/j.ccell.2016.10.010

Liu D, Tian S, Zhang K, Xiong W, Lubaki NM, Chen Z, Han W. 2017. Chimeric antigen receptor (CAR)-modified natural killer cell-based immunotherapy and immunological synapse formation in cancer and HIV. Protein Cell 8: 861877. doi:10.1007/s13238-017-0415-5

Llovet JM, Zucman-Rossi J, Pikarsky E, Sangro B, Schwartz M, Sherman M, Gores G. 2016. Hepatocellular carcinoma. Nat Rev Dis Primers 2: 16018. doi:10.1038/nrdp.2016 .18

Lynes J, Sanchez V, Dominah G, Nwankwo A, Nduom E. 2018. Current options and future directions in immune therapy for glioblastoma. Front Oncol 8: 578. doi:10.3389/ fonc.2018.00578

Mahoney KM, Rennert PD, Freeman GJ. 2015. Combination cancer immunotherapy and new immunomodulatory targets. Nat Rev Drug Discov 14: 561-584. doi:10.1038/ $\operatorname{nrd} 4591$

Marcus A, Gowen BG, Thompson TW, Iannello A, Ardolino M, Deng W, Wang L, Shifrin N, Raulet DH. 2014. Recognition of tumors by the innate immune system and natural killer cells. Adv Immunol 122: 91-128. doi:10 .1016/B978-0-12-800267-4.00003-1

Mascaux C, Angelova M, Vasaturo A, Beane J, Hijazi K, Anthoine G, Buttard B, Rothe F, Willard-Gallo K, Haller A, et al. 2019. Immune evasion before tumour invasion in early lung squamous carcinogenesis. Nature 571: 570575. doi:10.1038/s41586-019-1330-0

Massagué J. 2012. TGF $\beta$ signalling in context. Nat Rev Mol Cell Biol 13: 616-630. doi:10.1038/nrm3434

Matson V, Fessler J, Bao R, Chongsuwat T, Zha Y, Alegre ML, Luke JJ, Gajewski TF. 2018. The commensal microbiome is associated with anti-PD-1 efficacy in metastatic melanoma patients. Science 359: 104-108. doi:10.1126/science .aao3290

Mellman I, Coukos G, Dranoff G. 2011. Cancer immunotherapy comes of age. Nature 480: 480-489. doi:10.1038/ nature10673

Meng X, Liu X, Guo X, Jiang S, Chen T, Hu Z, Liu H, Bai Y, Xue M, Hu R, et al. 2018. FBXO38 mediates PD-1 ubiquitination and regulates anti-tumour immunity of $\mathrm{T}$ cells. Nature 564: 130-135. doi:10.1038/s41586-018-0756-0

Morvan MG, Lanier LL. 2016. NK cells and cancer: you can teach innate cells new tricks. Nat Rev Cancer 16: 7-19. doi:10.1038/nrc.2015.5

Mosser DM, Edwards JP. 2008. Exploring the full spectrum of macrophage activation. Nat Rev Immunol 8: 958-969. doi:10.1038/nri2448

Murdoch C, Giannoudis A, Lewis CE. 2004. Mechanisms regulating the recruitment of macrophages into hypoxic areas of tumors and other ischemic tissues. Blood 104: 2224-2234. doi:10.1182/blood-2004-03-1109

Noy R, Pollard JW. 2014. Tumor-associated macrophages: from mechanisms to therapy. Immunity 41: 49-61. doi:10 $.1016 /$ j.immuni.2014.06.010

O’Donnell JS, Teng MWL, Smyth MJ. 2019. Cancer immunoediting and resistance to T cell-based immunotherapy. Nat Rev Clin Oncol 16: 151-167. doi:10.1038/s41571018-0142-8

Paavonen J, Naud P, Salmerón J, Wheeler CM, Chow SN, Apter D, Kitchener H, Castellsague X, Teixeira JC, Skinner SR, et al. 2009. Efficacy of human papillomavirus (HPV)-16/18 AS04-adjuvanted vaccine against cervical infection and precancer caused by oncogenic HPV types (PATRICIA): final analysis of a double-blind, randomised study in young women. Lancet 374: 301-314. doi:10 .1016/S0140-6736(09)61248-4

Panigrahy D, Gartung A, Yang J, Yang H, Gilligan MM, Sulciner ML, Bhasin SS, Bielenberg DR, Chang J, Schmidt BA, et al. 2019. Preoperative stimulation of resolution and inflammation blockade eradicates micrometastases. J Clin Invest 129: 2964-2979. doi:10.1172/JCI127282

Papaioannou NE, Beniata OV, Vitsos P, Tsitsilonis O, Samara P. 2016. Harnessing the immune system to improve cancer therapy. Ann Transl Med 4: 261. doi:10.21037/ atm.2016.04.01

Pardoll DM. 2012. The blockade of immune checkpoints in cancer immunotherapy. Nat Rev Cancer 12: 252-264. doi:10.1038/nrc3239

Parsa AT, Waldron JS, Panner A, Crane CA, Parney IF, Barry JJ, Cachola KE, Murray JC, Tihan T, Jensen MC, et al. 2007. Loss of tumor suppressor PTEN function increases B7-H1 expression and immunoresistance in glioma. Nat Med 13: 84-88. doi:10.1038/nm1517

Pinho SS, Reis CA. 2015. Glycosylation in cancer: mechanisms and clinical implications. Nat Rev Cancer 15: 540555. doi: $10.1038 / \mathrm{nrc} 3982$ 
Poggio M, Hu T, Pai CC, Chu B, Belair CD, Chang A, Montabana E, Lang UE, Fu Q, Fong L, et al. 2019. Suppression of exosomal PD-L1 induces systemic anti-tumor immunity and memory. Cell 177: 414-427.e13. doi:10.1016/j .cell.2019.02.016

Porter DL, Levine BL, Kalos M, Bagg A, June CH. 2011. Chimeric antigen receptor-modified $\mathrm{T}$ cells in chronic lymphoid leukemia. New Engl J Med 365: 725-733. doi:10.1056/NEJMoa1103849

Quail DF, Joyce JA. 2013. Microenvironmental regulation of tumor progression and metastasis. Nat Med 19: 14231437. doi:10.1038/nm.3394

Rodríguez E, Schetters STT, van Kooyk Y. 2018. The tumour glyco-code as a novel immune checkpoint for immunotherapy. Nat Rev Immunol 18: 204-211. doi:10.1038/nri .2018 .3

Rohan TE, Xue X, Lin HM, D'Alfonso TM, Ginter PS, Oktay $\mathrm{MH}$, Robinson BD, Ginsberg M, Gertler FB, Glass AG, et al. 2014. Tumor microenvironment of metastasis and risk of distant metastasis of breast cancer. J Natl Cancer Inst 106. doi:10.1093/jnci/dju136

Rosenberg SA. 2014. IL-2: the first effective immunotherapy for human cancer. J Immunol 192: 5451-5458. doi:10 .4049/jimmunol.1490019

Rosenberg SA, Restifo NP. 2015. Adoptive cell transfer as personalized immunotherapy for human cancer. Science 348: 62-68. doi:10.1126/science.aaa4967

Rosenberg SA, Mule JJ, Spiess PJ, Reichert CM, Schwarz SL. 1985. Regression of established pulmonary metastases and subcutaneous tumor mediated by the systemic administration of high-dose recombinant interleukin 2. J Exp Med 161: 1169-1188. doi:10.1084/jem.161.5 .1169

Rosenberg SA, Yang JC, Sherry RM, Kammula US, Hughes MS, Phan GQ, Citrin DE, Restifo NP, Robbins PF, Wunderlich JR, et al. 2011. Durable complete responses in heavily pretreated patients with metastatic melanoma using T-cell transfer immunotherapy. Clin Cancer Res 17: 4550-4557. doi:10.1158/1078-0432.CCR-11-0116

Routy B, Le Chatelier E, Derosa L, Duong CPM, Alou MT, Daillère R, Fluckiger A, Messaoudene M, Rauber C, Roberti MP, et al. 2018. Gut microbiome influences efficacy of PD-1-based immunotherapy against epithelial tumors. Science 359: 91-97. doi:10.1126/science.aan3706

Sanmamed MF, Chen L. 2018. A paradigm shift in cancer immunotherapy: from enhancement to normalization. Cell 175: 313-326. doi:10.1016/j.cell.2018.09.035

Schildberg FA, Klein SR, Freeman GJ, Sharpe AH. 2016. Coinhibitory pathways in the B7-CD28 ligand-receptor family. Immunity 44: 955-972. doi:10.1016/j.immuni .2016 .05 .002

Schmidt A, Oberle N, Krammer PH. 2012. Molecular mechanisms of treg-mediated T cell suppression. Front Immunol 3: 51 .

Seidel JA, Otsuka A, Kabashima K. 2018. Anti-PD-1 and anti-CTLA-4 therapies in cancer: mechanisms of action, efficacy, and limitations. Front Oncol 8: 86. doi:10.3389/ fonc.2018.00086

Sharma P, Allison JP. 2015. The future of immune checkpoint therapy. Science 348: 56-61. doi:10.1126/science .aaa8172
Sharma P, Hu-Lieskovan S, Wargo JA, Ribas A. 2017. Primary, adaptive, and acquired resistance to cancer immunotherapy. Cell 168: 707-723. doi:10.1016/j.cell.2017.01 .017

Smith MJ, Culhane AC, Killeen S, Kelly MA, Wang JH, Cotter TG, Redmond HP. 2008. Mechanisms driving local breast cancer recurrence in a model of breast-conserving surgery. Ann Surg Oncol 15: 2954-2964. doi:10.1245/ s10434-008-0037-5

Sockolosky JT, Trotta E, Parisi G, Picton L, Su LL, Le AC, Chhabra A, Silveria SL, George BM, King IC, et al. 2018. Selective targeting of engineered T cells using orthogonal IL-2 cytokine-receptor complexes. Science 359: 10371042. doi:10.1126/science.aar3246

Svane IM, Verdegaal EM. 2014. Achievements and challenges of adoptive T cell therapy with tumor-infiltrating or blood-derived lymphocytes for metastatic melanoma: what is needed to achieve standard of care? Cancer Immunol Immunother 63: 1081-1091. doi:10.1007/s00262014-1580-5

Swann JB, Smyth MJ. 2007. Immune surveillance of tumors. J Clin Invest 117: 1137-1146. doi:10.1172/JCI31405

Tauriello DVF, Palomo-Ponce S, Stork D, Berenguer-Llergo A, Badia-Ramentol J, Iglesias M, Sevillano M, Ibiza S, Canellas A, Hernando-Momblona X, et al. 2018. TGF $\beta$ drives immune evasion in genetically reconstituted colon cancer metastasis. Nature 554: 538-543. doi:10.1038/na ture25492

Topalian SL, Drake CG, Pardoll DM. 2015. Immune checkpoint blockade: a common denominator approach to cancer therapy. Cancer Cell 27: 450-461. doi:10.1016/j.ccell .2015.03.001

Van Gool SW. 2015. Brain tumor immunotherapy: what have we learned so far? Front Oncol 5: 98. doi:10.3389/ fonc. 2015.00098

Wang D, DuBois RN. 2015. Immunosuppression associated with chronic inflammation in the tumor microenvironment. Carcinogenesis 36: 1085-1093. doi:10.1093/carcin/ bgv123

Wang M, Zhao J, Zhang L, Wei F, Lian Y, Wu Y, Gong Z, Zhang S, Zhou J, Cao K, et al. 2017. Role of tumor microenvironment in tumorigenesis. J Cancer 8: 761-773. doi:10.7150/jca. 17648

Wang J, Sanmamed MF, Datar I, Su TT, Ji L, Sun J, Chen L, Chen Y, Zhu G, Yin W, et al. 2019. Fibrinogen-like protein 1 is a major immune inhibitory ligand of LAG-3. Cell 176: 334-347.e12. doi:10.1016/j.cell.2018.11.010

Wculek SK, Malanchi I. 2015. Neutrophils support lung colonization of metastasis-initiating breast cancer cells. Nature 528: 413-417. doi:10.1038/nature 16140

Wolchok JD, Chiarion-Sileni V, Gonzalez R, Rutkowski P, Grob JJ, Cowey CL, Lao CD, Wagstaff J, Schadendorf D, Ferrucci PF, et al. 2017. Overall survival with combined nivolumab and ipilimumab in advanced melanoma. New Engl J Med 377: 1345-1356. doi:10.1056/NEJ Moa1709684

Xu J, Lamouille S, Derynck R. 2009. TGF- $\beta$-induced epithelial to mesenchymal transition. Cell Res 19: 156-172. doi:10.1038/cr.2009.5

Yang L, Pang Y, Moses HL. 2010. TGF- $\beta$ and immune cells: an important regulatory axis in the tumor microenviron- 
J.-H. Cha et al.

ment and progression. Trends Immunol 31: 220-227. doi:10.1016/j.it.2010.04.002

Yang Y, Li CW, Chan LC, Wei Y, Hsu JM, Xia W, Cha JH, Hou J, Hsu JL, Sun L, et al. 2018. Exosomal PD-L1 harbors active defense function to suppress $\mathrm{T}$ cell killing of breast cancer cells and promote tumor growth. Cell Res 28: 862-864. doi:10.1038/s41422 018-0060-4

Yang Y, Hsu JM, Sun L, Chan LC, Li CW, Hsu JL, Wei Y, Xia W, Hou J, Qiu Y, et al. 2019. Palmitoylation stabilizes PDL1 to promote breast tumor growth. Cell Res 29: 83-86. doi:10.1038/s41422-018-0124-5
Yao H, Lan J, Li C, Shi H, Brosseau JP, Wang H, Lu H, Fang C, Zhang Y, Liang L, et al. 2019. Inhibiting PD-L1 palmitoylation enhances $\mathrm{T}$-cell immune responses against tumours. Nat Biomed Eng 3: 306-317. doi:10.1038/s41551019-0375-6

Zhao X, Xu Z, Li H. 2017. NSAIDs use and reduced metastasis in cancer patients: results from a meta-analysis. $S c i$ Rep 7: 1875. doi:10.1038/s41598-017-01644-0

Zou W, Wolchok JD, Chen L. 2016. PD-L1 (B7-H1) and PD1 pathway blockade for cancer therapy: mechanisms, response biomarkers, and combinations. Sci Transl Med 8: 328rv4. doi:10.1126/scitranslmed.aad7118 


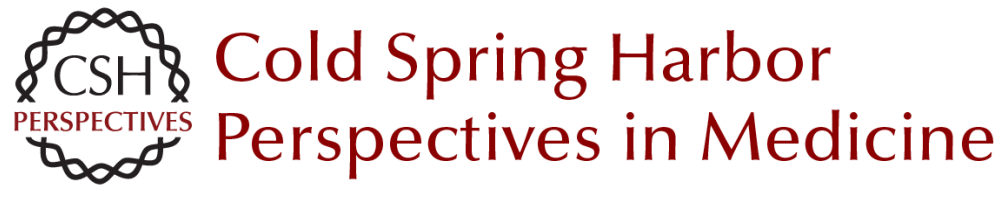

\section{New Approaches on Cancer Immunotherapy}

Jong-Ho Cha, Li-Chuan Chan, Min Sup Song and Mien-Chie Hung

Cold Spring Harb Perspect Med 2020; doi: 10.1101/cshperspect.a036863 originally published online October 15, 2019

Subject Collection Metastasis: Mechanism to Therapy

Cellular Plasticity during Metastasis: New Insights Provided by Intravital Microscopy Andreia S. Margarido, Laura Bornes, Claire Vennin, et al.

The Etiology and Impact of Muscle Wasting in Metastatic Cancer Anup K. Biswas and Swarnali Acharyya

Normal Aging and Its Role in Cancer Metastasis Mitchell Fane and Ashani T. Weeraratna

\section{Zebrafish In Vivo Models of Cancer and Metastasis \\ Katy R. Astell and Dirk Sieger \\ Extracellular Vesicles and Metastasis Shizhen Emily Wang}

The Different Facets of Liquid Biopsy: A Kaleidoscopic View

Zahra Eslami-S, Luis Enrique Cortés-Hernández, Laure Cayrefourcq, et al.

Myeloid Cells in Metastasis Agnieszka Swierczak and Jeffrey W. Pollard

Cancer Cell Dormancy in Metastasis Matthew A. Summers, Michelle M. McDonald and Peter I. Croucher

\section{Premetastasis \\ Yoshiro Maru}

Bone Tropism in Cancer Metastases Hai Wang, Weijie Zhang, Igor Bado, et al.

Impact of Immunometabolism on Cancer
Metastasis: A Focus on T Cells and Macrophages
Nina C. Flerin, Sotiria Pinioti, Alessio Menga, et al.
New Approaches on Cancer Immunotherapy
Jong-Ho Cha, Li-Chuan Chan, Min Sup Song, et al.

Cancer Stem Cells and Epithelial-to-Mesenchymal Transition in Cancer Metastasis Toni Celià-Terrassa and Mohit Kumar Jolly

Clinical Perspectives in Brain Metastasis Krutika Deshpande, Ian Buchanan, Vahan Martirosian, et al.

Brain Metastasis Organotropism Arseniy E. Yuzhalin and Dihua Yu

The Immune Microenvironment and Cancer Metastasis Asmaa El-Kenawi, Kay Hänggi and Brian Ruffell

For additional articles in this collection, see http://perspectivesinmedicine.cshlp.org/cgi/collection/ 